\title{
Ecological aspects of lepidopteran caterpillar parasitoids from Caryocar brasiliense Camb. (Caryocaraceae) in a cerrado sensu stricto of Central Brazil
}

\author{
Sheila Rodrigues Rodovalho ${ }^{1,4}$, Raúl Alberto Laumann ${ }^{2}$ \& Ivone Rezende Diniz ${ }^{3}$ \\ Biota Neotropica $v 7$ (n3) - http://www.biotaneotropica.org.br/v7n3/pt/abstract?article +bn04207032007 \\ Data Received 04/09/06 \\ Revised 10/05/07 \\ Accepted 21/11/07 \\ ${ }^{1}$ Programa de Pós Graduação em Ecologia, Departamento de Zoologia - IB, \\ Campus Universitário Darcy Ribeiro, Universidade de Brasilia - UnB \\ Asa Norte CEP 70910-900, Brasília, DF, Brazil, \\ ${ }^{2}$ Empresa Brasileira de Pesquisa Agropecuária - EMBRAPA/CENARGEN, \\ Parque Estação Biológica W5 Norte / Final \\ Asa Norte, CP 02372, CEP 70770-900, Brasilia, DF, Brazil \\ http://www.cenargen.embrapa.br \\ ${ }^{3}$ Departamento de Zoologia, Campus Universitário Darcy Ribeiro, Universidade de Brasília - UnB, \\ CEP 70919-907, Brasília, DF, Brazil, http://www.unb.br/ib/zoo \\ ${ }^{4}$ Corresponding author: Sheila Rodrigues Rodovalho, \\ e-mail: sheilarodovalho@gmail.com,http://www.unb.br/ib/ecl/posecl
}

\begin{abstract}
Rodovalho, S.R., Laumann, R.A. \& Diniz, I.R. Ecological aspects of lepidopteran caterpillar parasitoids from Caryocar brasiliense Camb. (Caryocaraceae) in a cerrado sensu stricto of Central Brazil. Biota Neotrop. Sep/Dez 2007 vol. 7, no. 3 http://www.biotaneotropica.org.br/v7n3/pt/abstract?article+bn04207032007. ISSN 1676-0603.

This study quantified parasitoid occurrence on five lepidopteran caterpillars species that use Caryocar brasiliense as host plant, trying to verify if there was a direct relationship between host abundance and the proportion of parasitism; if leaf shelters served as cues or protection from parasitoids; if host size influenced the proportion of parasitism, and if attacks by Diptera were more frequent than by Hymenoptera. Searches for external folivorous caterpillars were carried out in an area of cerrado sensu stricto, from July/2003 to June/2004. Caterpillars were more parasitized when occurred on mature leaves. Nola sp. (Noctuiidae) had the highest proportion of parasitism and a negative correlation between their body size and parasitoid attack. Caterpillars that constructed shelters suffered lower parasitism than those exposed. Hymenopteran parasitoids were more abundant than Dipteran parasitoids attacking caterpillars on C. brasiliense leaves. In general, parasitoid species richness and the proportion of parasitism in lepidopteran caterpillar on C. brasiliense showed associations with host population density, their life strategy, diet and leaf nutritional quality.

Keywords: Cerrado host plant, density dependent parasitism, leaf shelter caterpillars, plant-insect interactions, tritrophic interactions, tropical Lepidoptera.
\end{abstract}

\section{Resumo}

Rodovalho, S.R., Laumann, R.A. \& Diniz, I.R. Aspectos ecológicos de parasitóides em lagartas de Lepidoptera em Caryocar brasiliense Camb. (Caryocaraceae) em um cerrado sensu stricto do Brasil Central. Biota Neotrop. Sep/Dez 2007 vol. 7, no. 3 http://www.biotaneotropica.org.br/v7n3/pt/ abstract?article+bn04207032007. ISSN 1676-0603

Este estudo quantificou a ocorrência de parasitóides em cinco espécies de lagartas de Lepidoptera que possuem Caryocar brasiliense como planta hospedeira, verificando se existe uma relação direta e positiva entre a abundância do hospedeiro e a proporção de parasitismo; se os abrigos utilizados pelas espécies de Lepidoptera atuam como pistas ou proteção contra os parasitóides; se o tamanho do hospedeiro influencia as taxas de parasitismo e se existe uma maior ocorrência de ataques de Diptera em comparação com Hymenoptera nas lagartas de Lepidoptera no cerrado do Distrito Federal, Brasil. O estudo foi realizado em uma área de cerrado sensu stricto da Fazenda Água Limpa no período de julho de 2003 a junho de 2004, à procura de lagartas folívoras externas. As lagartas foram mais parasitadas quando ocorreram em folhas maduras. Nola sp. (Noctuidae) apresentou a maior proporção de parasitismo em comparação com as outras espécies e foi a única espécie em que se verificou uma correlação negativa entre as taxas de parasitismo e o tamanho de seus indivíduos. As espécies de lagartas que constroem abrigos apresentaram menores porcentagens de parasitismo em comparação com as que vivem expostas. Os parasitóides da ordem Hymenoptera foram mais freqüentes que os Diptera. No geral, para as espécies de Lepidoptera em C. brasiliense, a riqueza de espécies de parasitóides e a porcentagem de parasitismo apresentaram associações com a densidade, a estratégia de vida, a dieta do hospedeiro e a qualidade nutricional da folha de C. brasiliense.

Palavras-chave: interações inseto planta, interações tri-tróficas, lepidópteros tropicais, planta hospedeira do Cerrado, parasitismo dependente da densidade. 


\section{Introduction}

General theory of population dynamics of herbivorous insects predicts that their regulation can be reached by host plant structure, diversity, phenology, distribution (bottom-up) and by pressure of natural enemies (predators and parasitoids) (top-down) (Hunter \& Price 1992, Stiling \& Rossi 1997, Stireman \& Singer 2003a). An important issue to understand these interactions is the knowledge of some ecological characteristics of the herbivorous insect population, like their life history, behavior and relationship with their host plants and how these characteristics influence the third trophic level.

Parasitoids are responsible for limiting the populations of herbivorous insects and they exert a strong selective pressure in several host behaviors including foraging (Weseloh 1993), shelter construction, and utilization of host plant chemistry (Monteiro 1990). Some parasitoid families use cues from the host plant selected by the herbivorous insects to find them instead of searching directly their prey (Weseloh 1993), and in many cases this behavior constitutes the main category in the host location process (Vinson 1981).

The most frequent parasitoids that attack lepidopteran caterpillars are Diptera (mostly Tachinidae) and Hymenoptera (Ichneumonidae, Braconidae and Chalcidoidea) (Weseloh 1993, Hawkins \& Sheehan 1994). It has been demonstrated that Tachinidae are the main parasitoids attacking caterpillar species in temperate (Sheehan 1994) and in some tropical regions (Gentry \& Dyer 2002). However, in Cerrado some studies have demonstrated that the Hymenoptera are the most frequent parasitoids that attack lepidopteran caterpillars (Morais et al. 1999, Morais et al. 1996).

To escape from parasitoids, caterpillar species adopt strategies like coloration, morphology and behaviors that difficult their location (Gentry \& Dyer 2002). In Cerrado it is possible to observe an "enemy-free space" strategy from lepidopteran species, because their abundance is higher in the early dry season (May), while parasitoid density increases in the early wet season (October) (Morais et al. 1999).

Leaf-shelter caterpillars are apparent to parasitoids due to their sedentary lifestyle (Hawkins 1994). Chemical tracks, like silk or feces accumulation, are consistent and static signals, making them easy to locate (Gentry \& Dyer 2002). On the other hand, there are studies showing that shelters act as protection against parasitoids, predators and desiccation, creating a favorable microclimate (Loeffer 1996, Le Corff et al. 2000).

Most studies in Cerrado about interactions between host plantsherbivorous insects-parasitoids are from galling insects (e.g. Fagundes et al. 2005) or from biological control in agroecossystems (e.g. Zacarin et al. 2004). Field studies relating caterpillar seasonality and parasitism occurrence through a variety of scales are necessary to understand the interactions among herbivorous insects and their parasitoids.

This work quantified the parasitoids that emerged from external leaf feeding caterpillar on Caryocar brasiliense Camb (Caryocaraceae), a common plant species on Cerrado biome, and addressed the following hypotheses: 1) there is a direct relationship between host abundance and proportion of parasitism (Barbosa et al. 2001); 2) leaf-shelters protect caterpillars from parasitoids (Loeffer 1996); 3) host body size influences negatively the proportion of parasitoid attacks in caterpillars (van Driesche et al. 1991); and 4) attacks by Diptera are lower than by Hymenoptera in C. brasiliense caterpillars (Morais et al. 1996).

\section{Material and Methods}

\section{Study area}

The study was conducted from July 2003 to June 2004 in an area of cerrado sensu stricto in Fazenda Água Limpa (FAL) (15 ${ }^{\circ} 55^{\prime} \mathrm{S}$ and $\left.47^{\circ} 55^{\prime} \mathrm{W}\right)$, at $1100 \mathrm{~m}$ of altitude with an average annual precipitation of $1600 \mathrm{~mm}$ (varying from 750 to $2000 \mathrm{~mm}$ ) and an average temperature of $20{ }^{\circ} \mathrm{C}$ (varing from 12 to $28^{\circ} \mathrm{C}$ ) (Ribeiro \& Walter 1998). The climate of this region is classified as Aw according to Köppen, with a wet and hot season from October to April and a dry and cold season from May to September.

\section{Host plant}

Caryocar brasiliense Camb (Caryocaraceae) is a typical Cerrado brevedesciduous tree with a foliar life time of about 12 months, occurring in relatively dense groups of trees in this biome (Maia 1999). Ratter et al. (2003) performed a floristic composition analysis in 376 areas of the Cerrado and Amazon savannah, and C. brasiliense was found in $61 \%$ of the areas studied, being one of the 25 most frequent species in these regions.

In Distrito Federal, C. brasiliense reaches $10 \mathrm{~m}$ height (Gribel 1986). The species has tortuous stem ranging from 30 to $40 \mathrm{~cm}$ in diameter, thick branches, with opposite trifoliar and hairy leaves (Maia 1999). According to Gribel (1986), during the dry season (May to September) this species begins to lose its leaves with simultaneous emission of buttons and flowers.

This species was selected for the study because it is very common in this region and also have a very economic importance. This species is the only of the genera that occurs in Distrito Federal. Another congeneric species, C. cuneatum Wittm, has a different distribution from C. brasiliense, occurring in areas of the cerrado near the Amazon Forest (Ratter et al. 2003).

\section{Methodology}

Thirty trees of $C$. brasiliense were inspected weekly searching for external folivorous caterpillars. All caterpillars found were collected and their body size was measured with a pachymeter in the laboratory. They were reared in individual plastic cups $(500 \mathrm{~mL})$ and labeled with the date of collection. Caterpillars were fed with fresh leaves of C. brasiliense every day, and pots were covered with polyethylene film to avoid drying the leaves. Emergence of adult Lepidoptera and parasitoids was recorded. Date of collection of caterpillar in the field study was considered to be the parasitism date. Dead caterpillars were maintained for seven days in the pots for the possible emergence of any parasitoids. Vitor O. Becker identified the Lepidoptera, and the parasitoids were separated into families and morphospecies of Hymenoptera and Diptera, which were then preserved in $70 \%$ alcohol. All individuals were deposited in the Entomological collection of the Zoology Department of the University of Brasilia.

Leaves on which caterpillars were found were classified into three relative age groups: a) new - expanding (small and reddish) and recently expanded (light green and flexible); b) mature - fully expanded rigid with dark green color; and c) old - rigid and brownish.

The four most abundant monophagous Lepidoptera caterpillar species with different strategies of foraging behavior (exposed on leaf surface or shelter building) were selected for this study. The first group included two caterpillar species that live exposed on leaves: Nola sp. (Noctuidae) and Rifargia onerosa Schaus, 1905 (Notodontidae). The second group included two species that build shelters: Rhodoneura intermedia (Warren 1908) (Thyrididae) and Phidotricha sp. (Pyralidae). The diet amplitude of these species was determined from the database of an ongoing research project in the Cerrado vegetation that includes about 100 host plant species monitored during at least a year.

\section{Statistical analysis}

To verify if there are differences between the dry and wet seasons in caterpillars and parasitoids abundance; if there are differences in 
host plant leaf age in caterpillars occurrence and parasitism rate; and, if there are differences in parasitism attacks between exposed and sheltered caterpillars chi-square tests were performed. Spearman's Correlation was used to verify relationship between caterpillar body size and parasitoid occurrence in all four species.

\section{Results}

Overall, 1440 plants were examined and 352 caterpillars of the four lepidopteran species were found in $C$. brasiliense leaves. Caterpillar abundance had a peak on May (early dry season). The lowest abundances were observed on September - October (transition between dry and wet season) and on December - January (middle of wet season). The number of parasitized caterpillars also varied, with a peak on May - June (Figure 1).

The abundance of the four species was significantly higher during the dry season $\left(\chi^{2}=70.8959 ; \mathrm{df}=3 ; \mathrm{P}<0.0001\right)$ (Table 1$)$. Parasitoid occurrence showed a similar pattern, being higher during the dry season $\left(\chi^{2}=4.5013 ; \mathrm{df}=1 ; \mathrm{P}<0.05\right)$. Nola sp. and $R$. onerosa occurred mainly during the dry season; $R$. intermedia presented a 10-month period of occurrence while Phidotricha sp. occurred only during brief intervals (Figure 2).

A total of 99 caterpillars were parasitized during the study period (Table 1). Exposed caterpillars occurring on mature an old leaves were more parasitized than sheltered caterpillars $\left(\chi^{2}=59.6939\right.$; $\mathrm{df}=1$; $\mathrm{P}<0.0001$ and $\left.\chi^{2}=4.7867 ; \mathrm{df}=1 ; \mathrm{P}<0.05\right)$. Table 2 shows that caterpillars present on mature leaves was significantly higher than on new and old leaves $\left(\chi^{2}=31.5516 ; \mathrm{df}=2 ; \mathrm{P}<0.0001\right)$. There was no difference between exposed and sheltered caterpillars found on old leaves of $C$. brasiliense $\left(\chi^{2}=0.6522 ; \mathrm{df}=1 ; \mathrm{P}>0.05\right)$

Nola sp. was the most abundant species found in C. brasiliense, with 159 caterpillars collected with $52.8 \%$ of them parasitized. The other three species had proportions of parasitism smaller than $10 \%$ (Table 1). Only in the case of Nola sp. the results showed a negative correlation between body size and parasitoid attacks $\left(\mathrm{R}_{\text {Spearman }}=-0.24753 ; \mathrm{P}<0.01\right)$.

There was a significant difference between parasitoid attack on sheltered $(13.1 \%)$ and exposed caterpillars $(86.9 \%)\left(\chi^{2}=59.0084\right.$; $\mathrm{df}=1 ; \mathrm{P}<0.0001)$. In the two most abundant species on $C$. brasiliense, Nola sp. and $R$. intermedia, it was observed that the first was more parasitized than the last during the dry season $\left(\chi^{2}=47.7916\right.$; $\mathrm{df}=1$;

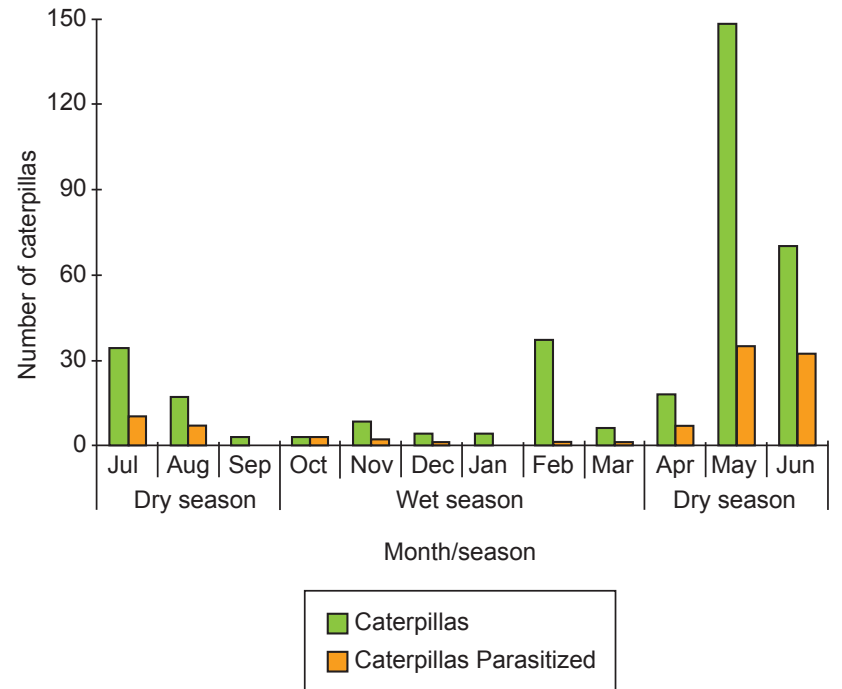

Figure 1. Number of caterpillars and parasitized caterpillars of the four commonest lepidopteran species found on C. brasiliense in a cerrado sensu stricto at the Fazenda Água Limpa in Distrito Federal, from July/2003 to June/2004.

Figura 1. Número total de lagartas de Lepidoptera encontradas e número total de lagartas parasitadas das quatro espécies mais comuns em C.brasiliense no cerrado sensu stricto da Fazenda Água Limpa - DF, durante o período de julho/2003 a junho/2004.

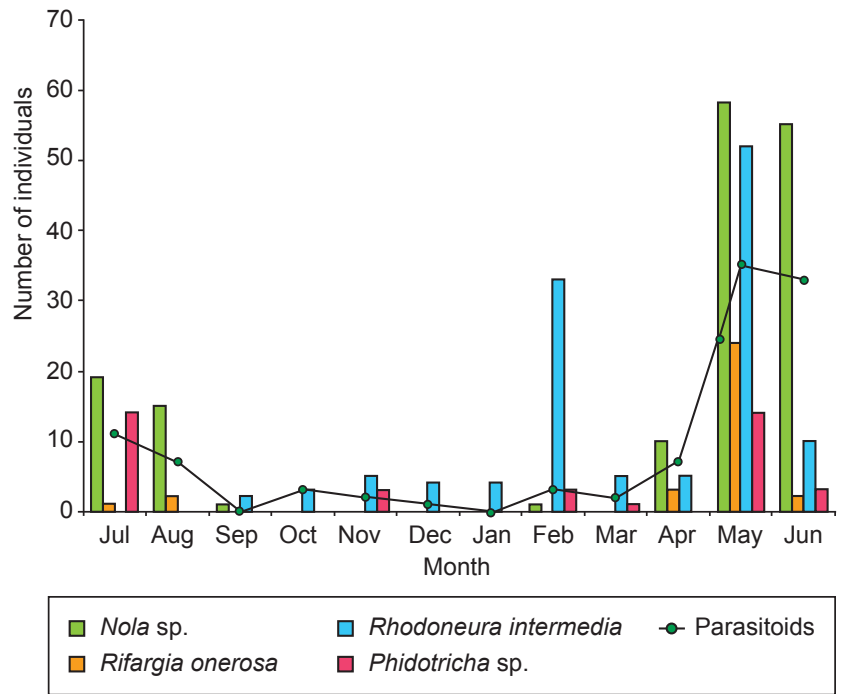

Figure 2. Occurrence of parasitoids and the four commonest lepidopteran caterpillars species collected from July/2003 to June/2004 on C. brasiliense in a cerrado sensu stricto at the Fazenda Água Limpa in Distrito Federal.

Figura 2. Ocorrência mensal de parasitóides e das quatro espécies de lagartas Lepidoptera coletadas em C. brasiliense no período de julho/2003 a junho/2004 em um cerrado sensu stricto da Fazenda Água Limpa - DF.

Table 1. Life strategy, number of lepidopteran caterpillars occurring during the dry and wet seasons and number of parasitized caterpillars collected on C. brasiliense in a cerrado sensu stricto at the Fazenda Água Limpa in Distrito Federal, from July/2003 to June/2004.

Tabela 1. Estratégia de vida, número de lagartas encontradas em C. brasiliense durante as estações seca e chuvosa e número de lagartas parasitadas nas quatro espécies de Lepidoptera durante o período de julho/2003 a julho/2004 em um cerrado sensu stricto da Fazenda Água Limpa, no Distrito Federal.

\begin{tabular}{llrrr}
\hline \multicolumn{1}{c}{ Species } & Life Strategy & \multicolumn{2}{c}{ Season } & \multirow{2}{*}{ Parasitized (\%) } \\
\cline { 3 - 5 } & & Wet $(\%)$ & Dry $(\%)$ & $84(52.8)$ \\
Nola sp. & exposed & $11(6.9)$ & $148(93.1)$ & $11(8.9)$ \\
R. intermedia & sheltered & $59(47.9)$ & $64(52.1)$ & $2(5.3)$ \\
R. onerosa & sheltered & $3(9.4)$ & $29(90.6)$ & $2(6.3)$ \\
Phidotricha sp. & exposed & $7(18.4)$ & $31(81.6)$ & \\
\hline
\end{tabular}


$\mathrm{P}<0.0001)$ whereas $R$. intermedia was more attacked during the wet season $\left(\chi^{2}=5.2851 ; \mathrm{df}=1 ; \mathrm{P}<0.05\right)$.

Table 3 shows that Hymenoptera (four morphoespecies) were the most abundant and frequent parasitoids, accounting for $92.0 \%$ of their occurrence. Braconidae was the family with the two most abundant morphospecies $(87)$. Chalcididae $(n=1)$ was found only in $R$. intermedia. One species of Braconidae occurred in all four lepidopteran species. The family Tachinidae (Diptera) was represented by two morphospecies with eight individuals. Among all lepidopteran species, $R$. intermedia had the highest parasitoid species richness $(n=6)$, followed by Nola $\mathrm{sp}$. $(\mathrm{n}=5)$.

\section{Discussion}

In Cerrado, it is possible that shelters provide protection against parasitoids during the dry season, as shown by the significantly smaller proportion of parasitism found in R. intermedia than in Nola sp. The antiparasitoid function attributed to the shelters is a controversial subject in literature. Some authors show that caterpillars with shelters are more attacked because they produce chemical (Gentry \& Dyer 2002) and visual cues (Hawkins 1994), but others like Jones et al. (2002) verified experimentally that shelters are important in caterpillar protection against parasitoid attack. Bernays (1997) also showed that exposed caterpillars were most often attacked by parasitoids due to their movement on the leaf while foraging, because movement is more important to some parasitoids than chemical cues.

It is known that there is a strong relationship between host body size and parasitoid occurrence (Stireman \& Singer 2003a). According to Gentry \& Dyer (2002), Hymenoptera are more abundant in smaller

Table 2. Number of total and parasitized of the five lepidopteran caterpillar species collected on different relative leaf age of $C$. brasiliense in a cerrado sensu stricto at the Fazenda Água Limpa in Distrito Federal, from July/2003 to June/2004.

Tabela 2. Número total de lagartas das quatro espécies de Lepidoptera e número de parasitóides ocorrentes nas três categorias de idade relativa das folhas de $C$. brasiliense no cerrado sensu stricto da Fazenda Água Limpa, Distrito Federal, no período de julho/2003 a junho/2004.

\begin{tabular}{lrcr}
\hline \multirow{1}{*}{ Species } & \multicolumn{3}{c}{ Relative Leaf Age } \\
\cline { 2 - 4 } & New & Mature & Old \\
\hline Nola sp. & $1(0)$ & $140(76)$ & $18(8)$ \\
R. intermedia & $27(6)$ & $95(5)$ & $1(0)$ \\
R. onerosa & $1(0)$ & $30(2)$ & $1(0)$ \\
Phidotricha sp. & $1(1)$ & $30(1)$ & $7(0)$ \\
TOTAL & $30(7)$ & $295(84)$ & $27(8)$ \\
\hline
\end{tabular}

caterpillars, and Diptera occurs with larger frequency in host's last instars, or in species with larger body size, like Saturniidae. In this study, only Nola sp. showed a relation between caterpillar size and parasitism. The negative correlation found in this species and the dominance of Hymenoptera parasitoids attacking it (95.2\% of caterpillars parasitized) support the hypotheses of Gentry \& Dyer (2002).

Parasitism frequency in lepidopteran caterpillars by Diptera and Hymenoptera varies in different regions and ecosystems. For example, Diptera is the most common kind of parasitoid occurring in temperate regions. Stireman \& Singer (2003b) showed that of the $18.4 \%$ parasitism attack in G. geneura, $14.7 \%$ were by Diptera and $3.7 \%$ by Hymenoptera. Sheehan (1994) encountered that $39 \%$ of the caterpillars were parasitized by Tachinidae and $17.5 \%$ by Hymenoptera. Even in a tropical region of Costa Rica, Janzen (1995) found a similar pattern of Diptera dominancy (7\% of the caterpillars were parasitized by Diptera and $3 \%$ by Hymenoptera). The parasitoids found on caterpillars from $C$. brasiliense did not follow the patterns found by these authors; instead, Hymenoptera reached $92.4 \%$ of the 99 parasitized caterpillars.

Parasitoid species richness and parasitism proportions in caterpillars on $C$. brasiliense were related to host population density (abundance) and to their life strategy (living exposed or in shelters). Considering host body size, only for Nola sp. the attacks of parasitism could be associated with earlier instar caterpillars. However, to test if the pattern found in this study can be generalized for Cerrado, further studies must be done involving comparative analyses of parasitism in lepidopteran caterpillars on other host plant species of this biome.

\section{Acknowledgments}

We thanks Barbara Higgins for assistance in the field. We would like to express our gratitude to Vitor O. Becker, who identified the lepidopteran species, to M. Haridasan for reviewing and provide valuable comments to this manuscript, to Helena C. Morais and John Du Val Hay for comments and discussions. Finally for The Brazilian National Council of Scientific and Technological Development (CNPq) for financial supports during the years 2003 and 2004.

\section{References}

BARBOSA, P., SEAGRA, A.E., CALDAS, P., AHLSTRHM, K., CARLSON, R.W., FERGUSON, D.C., GRISSEL, E.E., HODGES, R.W. MARSH, P.M., POOLE, R.W., SCHAUFF, M.E. WHITFIELD, J. B. \& WOODLEY, N.E. 2001. Differential parasitism of macrolepidopteran herbivores on two deciduous tree species. Ecology. 82:698-704.

BERNAYS, E.A. 1997. Feeding by lepidopteran larvae is dangerous. Ecol. Entomol. 22:121-123.

Table 3. Occurrence of parasitoid species in the four lepidopteran caterpillar species collected on C. brasiliense in a cerrado sensu stricto at the Fazenda Água Limpa in Distrito Federal, from July/2003 to June/2004 at FAL.

Tabela 3. Ordens e famílias de parasitóides ocorrentes nas lagartas das quatro espécies de Lepidoptera coletadas em C. brasiliense em um cerrado sensu stricto da Fazenda Água Limpa do Distrito Federal, no período de julho/2003 a junho/2004

\begin{tabular}{|c|c|c|c|c|c|}
\hline \multicolumn{2}{|c|}{ Parasitoid } & \multicolumn{2}{|c|}{ Exposed } & \multicolumn{2}{|c|}{ Shelter } \\
\hline Order & Family & Nola sp. & R. onerosa & Phidotricha sp. & R. intermedia \\
\hline \multirow[t]{3}{*}{ Hymenoptera } & Ichneumonidae & 2 & 0 & 0 & 1 \\
\hline & Braconidae & 78 & 2 & 2 & 5 \\
\hline & Chalcididae & 0 & 0 & 0 & 1 \\
\hline \multirow[t]{2}{*}{ Diptera } & Tachinidae & 4 & 0 & 0 & 4 \\
\hline & Total & 84 & 2 & 2 & 11 \\
\hline
\end{tabular}


FAGUNDES, M., NEVES, F.S. \& FERNANDES, G.W. 2005. Direct and indirect interactions involving ants, insect herbivores, parasitoids, and the host plant Baccharis dracunculifolia (Asteraceae). Ecol. Entomol. 30:28-35.

GENTRY, G.L. \& DYER, L.A. 2002. On the conditional nature of neotropical caterpillar defenses against their natural enemies. Ecology. 83:3108-3119.

GRIBEL, R. 1986. Ecologia da polinização e da disperção de Caryocar brasiliense Camb. (Caryocaraceae) na região do Distrito Federal. Dissertação de Mestrado, Universidade de Brasília, Distrito Federal.

HAWKINS, B.A. 1994. Pattern and process in host-parasitoid interactions. Cambridge University Press, Cambridge.

HAWKINS, B.A. \& SHEEHAN, W. 1994. Parasitoid community ecology. Oxford University Press, New York.

HUNTER, A.F. \& ELKINTON, J.S. 1999. Interaction between phenology and density effects on mortality from natural enemies. J. Anim. Ecol. 68:1093-1100.

HUNTER, M.D. \& PRICE, P.W. 1992. Playing chutes and ladders: Heterogeneity and the relative roles of bottom-up and top-down forces in natural communities. Ecology. 73:724-732.

JANZEN, D.H. 1995. The caterpillars and their parasitoids of a tropical dry forest. Tach. Times 1:2-5.

JONES, M.T., CASTELLANOS, I. \& WEISS, M.R. 2002. Do leaf shelters always protect caterpillars from invertebrate predators? Ecol. Entomol. 27:753-757.

LE CORFF, J., MARQUIS, R.J. \& WHITFIELD, J.B. 2000. Temporal and spatial variation in a parasitoid community associated with the herbivores that feed on Missouri Quercus. Environ. Entomol. 29:181-194.

LOEFFER, C.C. 1996. Adaptative trade-offs of leaf folding in Dichomeris caterpillars on goldenrods. Ecol. Entomol. 21:34-40.

MAIA, J.M.F. 1999. Variações sazonais das relações fotossintéticas, hídricas e crescimento de Caryocar brasiliense e Rapanea guianensis em um cerrado sensu stricto. Dissertação de Mestrado, Universidade de Brasília, Distrito Federal.

MONTEIRO R.F. 1990. Crypt larval polychromatism in Recoa marius Lucas and $R$. palegon Cramer (Lycaenidae: Theclinae). J. Res. Lepidoptera. 29:77-84.

MORAIS, H.C. DINIZ, I.R. \& SILVA, D.M.S. 1999. Caterpillar seasonality in a central Brazilian cerrado. Rev. Biol. Trop. 47: 1025-1033.
MORAIS, H.C., DINIZ, I.R. \& SILVA, J.R. 1996. Larvas de Siderone marthesia nemesis (Illiger) (Lepidoptera, Nymphalidae, Charaxinae) em cerrado de Brasília, Distrito Federal, Brasil. Rev. Bras. Zoo. 13:351-356.

RATTER, J.A., BRIDGEWATER, S. \& RIBEIRO, J.F. 2003. Analysis of the floristic composition of the Brazilian Cerrado vegetation III: Comparison of the woody vegetation of 376 areas. Edinburgh. J. Bot. 60:57-109.

RIBEIRO, J.F. \& WALTER, B.M.T. 1998. Fitofisionomias do Bioma Cerrado. In Cerrado: Ambiente e Flora. (S.M. Sano \& S.P. Almeida, eds). EMBRAPA-CPAC, Planaltina. p. 89-166.

SHEEHAN, W. 1994. Parasitoid community structure: effects of host abundance, phylogeny and ecology. Parasitoid community ecology (B.A. Hawkins \& W. Sheehan, eds). Oxford University Press, New York. p. $90-107$

STILING, P. \& ROSSI, A.M. 1997. Experimental manipulations of top-down and bottom-up factors in a tri-trophic system. Ecology, 78:1602-1606.

STIREMAN, J.O. \& SINGER, M.S. 2002. Spatial and temporal variation in the parasitoid assemblage of an exophytic polyphagous caterpillar. Ecol. Entomol. 27:588-600.

STIREMAN, J.O. \& SINGER, M.S. 2003a. Determinants of parasitoid -host associations: insights from a natural tachinid-lepidopteran community. Ecology. 84:296-316.

STIREMAN, J.O. \& SINGER, M.S. 2003b. What determines host range in parasitoids? An analysis of a tachinid parasitoid community. Oecologia. 135:629-638.

VAN DRIESCHE, R.G., BELLOWS, T.S., ELKINGTON, J.S., GOULD, J.R. \& FERRO, D.N. 1991. The meaning of percentage parasitism revisited: solutions to the problem of accurately estimating total losses from parasitism. Environ. Entomol. 20:1-7.

VINSON, S.B. 1981. Habitat location. Semiochemicals: Their role in pest control. (D.A. Nordlund, R.L. Jones \& W.J. Lewis, eds). Wiley, New York. p. 51-77

WESELOH, R.M. 1993. Potential effects of parasitoids on the evolution of caterpillar foraging behavior. Caterpillar: ecological and evolutionary constraints on foraging. (N.C. Stamp \& T.M. Casey, eds). Chapman \& Hall Press, New York. p. 203-223.

ZACARIN, G.G., GOBBI, N. \& CHAUD-NETTO, J. 2004. Capacidade reprodutiva de fêmeas de Apanteles galleriae (Hymenoptera, Braconidae) em lagartas de Galleria mellonella e Achroia grisella (Lepidoptera, Pyralidae) criadas com dietas diferentes. Iheringia. 94:139-147. 
